\title{
FACTORS AFFECTING CONSUMER-BASED BRAND EQUITY OF VIETNAMESE PHARMACEUTICAL COMPANIES
}

\author{
Nguyen Cao Quynh Tu ${ }^{a^{*},}$ Luu Tien Dung
}

${ }^{a}$ The Faculty of Pharmacy, Lac Hong University, Dongnai, Vietnam

${ }^{b}$ The Faculty of Business Administration - International Economics, Lac Hong University, Dongnai, Vietnam

*Corresponding author: Email: quynhtucr1202@gmail.com

Article history

Received: March 10 $0^{\text {th }}, 2018$

Received in revised form: April 08 ${ }^{\text {th }}, 2018$ | Accepted: May 02 ${ }^{\text {nd }}, 2018$

\begin{abstract}
The concept and importance of a company's brand have always been widely acknowledged. However, in modern Vietnam, many Vietnamese companies are still unaware of the importance of building their brand. Particularly in the pharmaceutical industry where products are directly related to human health, buying products of famous pharmaceutical brands to help ensure the lowest risk is gradually becoming a habit of consumers. The purpose of this paper is to find out factors affecting consumer-based brand equity of Vietnamese pharmaceutical companies. The study provides a conceptual framework in which brand awareness, brand associations, perceived quality and brand loyalty are related to brand equity. The survey was conducted on a sample of 328 customers at pharmacies and hospitals in Vietnam who have basic knowledge on some of Vietnamese pharmaceutical companies' brands. The research instruments included an 18-item questionnaire on brand equity, plus demographic questions. Results show that there are four factors affecting the brand equity of Vietnamese pharmaceutical companies, including brand awareness, brand associations, perceived quality, brand loyalty and the correlation between them.
\end{abstract}

Keywords: Brand associations; Brand awareness; Brand equity; Brand loyalty; Perceived quality; Pharmaceutical companies.

Article identifier: http://tckh.dlu.edu.vn/index.php/tckhdhdl/article/view/432

Article type: (peer-reviewed) Full-length research article

Copyright (C) 2018 The authors.

Licensing: This article is licensed under a CC BY-NC-ND 4.0 


\title{
CÁC YẾU TỐ TÁC ĐộNG ĐẾN GIÁ TR! THƯƠNG HIỆU CỦA CÁC DOANH NGHIÊP DƯợC VIÊTT NAM DƯớI GÓC NHÌN CỦA NGƯÒII TIÊU DÙNG
}

\author{
Nguyễn Cao Quỳnh Túa ${ }^{a^{*}, \text { Lưu Tiến Dũng }}{ }^{b}$ \\ ${ }^{a}$ Khoa Duợc, Truờng Đại học Lac Hồng, Đồng Nai, Việt Nam \\ ${ }^{b}$ Khoa Quản trị Kinh doanh - Kinh tế Quốc tế, Trường Đại hoc Lac Hồng, Đồng Nai, Việt Nam \\ "Tác giả liên hệ: Email: quynhtucr1202@gmail.com
}

Lịch sử bài báo

Nhận ngày 10 tháng 03 năm 2018

Chỉnh sửa ngày 08 tháng 04 năm 2018 | Chấp nhận đăng ngày 02 tháng 05 năm 2018

\section{Tóm tắt}

Khái niệm và tầm quan trọng của thuoong hiệu doanh nghiệp luôn được công nhận rộng rãi. Tuy nhiên, hiện nay, nhiều doanh nghiệp Việt Nam vẫn không ý thức được về tầm quan trọng của việc xây dựng thuơng hiệu, đặc biệt trong ngành duợc phẩm nờ mà sản phẩm có liên quan trục tiếp đến sức khoe con nguời, thì việc mua sản phẩm của các thương hiệu duợc nổi tiếng giúp đảm bảo nguy co thấp nhất đang dần trở thành thói quen của nguời tiêu dùng. Mục đích của bài báo này là tìm ra các yếu tố tác động đến giá trị thuơng hiệu dựa trên nguời tiều dùng của các doanh nghiệp dược phẩm Việt Nam. Nghiên cúu cung cấp khuôn khổ khái niệm trong đó nhận thức thuơng hiệu, liên tuơơng thuơng hiệu, chất luợng cảm nhận và lòng trung thành của thuoong hiệu có liên quan đến giá trị thuoong hiệu. Cuộc khảo sát được thực hiện trên 328 khách hàng tại các nhà thuốc và bệnh viện ở Việt Nam có kiến thức co bản về thuoong hiệu của các doanh nghiệp duợc phẩm Việt Nam. Công cu nghiên cứu bao gồm 18 muc hỏi về giá trị thuoong hiệu, cộng với việc khảo sát nhân khẩu học. Kết quả tìm ra bốn yếu tố tác động đến giá trị thưong hiệu của các doanh nghiệp duợc phẩm Việt Nam, bao gồm nhận thức thuong hiệu, liên twởng thuoong hiệu, chất luợng cảm nhận, lòng trung thành thuơng hiệu và sụ tuoong quan giũa chúng.

Từ khóa: Chất lượng cảm nhận; Doanh nghiệp dược phẩm; Giá trị thương hiệu; Liên tưởng thương hiệu; Lòng trung thành thương hiệu; Nhận thức thương hiệu.

Mã số định danh bài báo: http://tckh.dlu.edu.vn/index.php/tckhdhdl/article/view/432

Loại bài báo: Bài báo nghiên cứu gốc có bình duyệt

Bản quyền $\odot 2018$ Các tác giả.

Cấp phép: Bài báo này được cấp phép theo CC BY-NC-ND 4.0 


\section{INTRODUCTION}

Vietnam's pharmaceutical market is considered an attractive market for investors, with the top growth rate in Southeast Asia. According to Business Monitor International (2018), in 2016, Vietnamese pharmaceutical market expenditure was estimated to reach $\$ 4.7$ billion, an increase of $12 \%$ over the previous year and is expected to increase to about $\$ 7.7$ billion by 2021 . As a result, Vietnam is a deeply decentralized and fragmented market with over 1,000 drugs wholesalers or distributors, leading to a fiercer competition in the industry (Business Sweden, 2015). In the context of competition where consumers have many choices, brands become the means to help consumers identify the differences and choose the best option. Therefore, if a pharmaceutical company would like to grow and survive, it is necessary to focus on building its brand. However, there are still many other pharmaceutical companies that do not pay attention to building a distinct brand name. They are unaware that brands can decide the success of a company in long-term development. Christodoulides, Cadogan, and Veloutsou (2015) asserted that we need to generate a better understanding of the composition of brand equity to understand how to manage brand equity.

Brand equity was first mentioned by Farquhar (1989) as the 'added value' of a product. Then there are many other studies on brand equity in the world. Typically, there are researches conducted by Aaker (1991); Musekiwa, Chiguvi, and Hogo (2013); Wang and Finn (2013); and Yoo, Donthu, and Lee (2000). Aaker (1991) provided the theory of brand equity and its components as the basis for building and developing a brand. Yoo et al. (2000) conducted an examination of selected marketing mix elements and brand equity on three product categories, that is, athletic shoes, camera film, and color television sets. Wang and Finn (2013) studied heterogeneous sources of customer-based brand equity within a product category (i.e. soft drinks). Musekiwa et al. (2013) carried out a study to determine the nature of the relationship between retail brand equity dimensions and retail brand equity for OK supermarket in Bindura. In Vietnam, there have also been many studies on brand equity. Ngo, Nguyen, and Dinh (2014) searched components of brand equity in the case of Binhthuan dragon fruit. Hoang (2016) examined the impact of advertising and promotion on brand equity of the FMCG supermarket industry in Hue. However, so far there has been no firm official research on brand equity of Vietnamese pharmaceutical companies. Recognizing the urgency of this issue, the study conducted a survey on the factors affecting brand equity of Vietnamese pharmaceutical companies.

The objectives of this study were to determine the factors affecting the brand equity of Vietnamese pharmaceutical companies, as well as to explore the consumer-based brand equity practice scale, and propose some recommendations for brand-building for pharmaceutical companies in Vietnam. The research was based on Aaker's brand equity model in 1991 and was adapted to fit the characteristics of the pharmaceutical industry. The article consists of five parts, including (1) Introduction; (2) Literature review; (3) Methodology; (4) Results and discussions; and (5) Conclusions.

\section{LITERATURE REVIEW}

Brand equity is a multidimensional and complex concept. The meaning of the term is discussed from different angles for different purposes. At present, brand equity is based on two main perspectives: Financial perspective and consumer perspective. In marketing 
research, consumer-based brand equity valuation is supported by more scholars because brand equity is the result of consumers' perception of that brand (Vázquez, Del Rio, \& Iglesias, 2002; Wang \& Finn, 2013; Yoo et al., 2000). Therefore, this study mostly discusses brand equity from a consumer perspective.

Customer-based brand equity is defined as the disparate impact of brand knowledge on consumer response to the marketing of the brand (Keller, 1993). According to Aaker (1991), brand equity is a class of assets and liabilities connected to the brand name and brand symbol that add to or subtract the value of a product or service to a firm and its customers. It also can be defined as the marketing and financial value linked to a brand's place in the marketplace (Ferrell \& Hartline, 2011) or the overall utility that the consumer connects to the utilization of the brand about both functional and symbolic utilities (Vázquez et al., 2002).

There are many models of brand equity being offered such as the models by Aaker (1991); Wang and Finn (2013); and Yoo et al. (2000). Aaker (1991) said that brand equity can be grouped into five categories: Brand loyalty; Name awareness; Perceived quality; Brand associations; and other proprietary brand assets. Yoo et al. (2000) proposed brand equity measured by the interaction of factors including perceived quality, brand loyalty and brand awareness/associations. Wang and Finn (2013) suggested seven dimensions of brand equity: Past brand loyalty; Current brand awareness; Current perceived quality; Current perceived value for the cost; Current brand associations; Uniqueness; and Brand emotions.

This study is based on David Aaker's model, which has been tested on a variety of products by many scientists (Atilgan, Aksoy, \& Akinci, 2005; Christodoulides et al., 2015; Musekiwa et al., 2013; Pappu, Quester, \& Cooksey, 2005) and is considered one of the most generalized brand equity measurement models. In addition, the experts, pharmacists, doctors interviewed by the authors also suggested that Aaker's model is suitable for research on the pharmaceutical market. However, the fifth factor (i.e. other proprietary brand assets) is almost not mentioned later in the studies of other authors (Keller, 1993; Wang \& Finn, 2013; \& Yoo et al., 2000) because this factor is not really associated with consumers and marketing. Accordingly, the authors suggest four factors affecting brand equity: Brand awareness; Brand associations; Perceived quality; and Brand loyalty.

\subsection{Brand awareness}

At the present, because there are so much information and media, the creation of customer perception with a brand is really necessary. Aaker (1991) defined brand awareness is the ability of a potential customer to recognize or recall that a brand is a part of a certain product category. According to Keller (1993), brand awareness includes brand recognition and brand recall performance. Brand recognition reflects familiarity gained from past contact and brand recall comes to consumer's minds when one product is mentioned (Aaker, 1996). Panchal, Khan, and Ramesh (2012) believe that people will often buy a familiar brand because they feel comfortable with the familiarity and that brand is probably reliable and of good quality. Atilgan et al. (2005) postulated that customerbased brand equity happens when the consumer has a high level of awareness and holds some special, strong and good brand associations in memory. Studies have confirmed that brand awareness has a positive effect on brand equity (Aaker, 1991; Atilgan et al., 2005; 
Keller, 1993; Musekiwa et al., 2013; Panchal et al., 2012; Pappu et al., 2005; Wang \& Finn, 2013; Yoo et al., 2000). Therefore, the first hypothesis would be:

- H1: Brand awareness has a positive impact on brand equity.

\subsection{Brand associations}

Aaker (1991) defined brand associations are anything connect to the memory of customers to a brand. Brand associations can be divided into product associations and organizational associations. Product associations can consist of quality, price, and usage; organizational associations would contain corporate ability and corporate social onus (Musekiwa et al., 2013). Chen (2001) and Yoo et al. (2000) argued that brand association is one of the core elements of a brand. Customers will think of one or a few features of a particular brand when the brand is mentioned. Brand associations create equity for the company and its customers by providing information, create positive attitudes and emotions, provide the reason to buy the product, differentiating and positioning the brand. Atilgan et al. (2005) discovered that associations create a base for purchase decisions and value to the firm and customers. Consumers use brand name to surmise quality of an unfamiliar product because a brand name has been built based on its associations with quality, value or utility of its products (Lassar, Mittal, \& Sharma, 1995). Río, Vázquez, and Iglesias (2001) proposed that consumers' brand associations are a crucial element in brand equity origination and management. Previous studies showed that brand associations are directly related to brand equity (Chen, 2001; Keller, 1993; Musekiwa et al., 2013; Pappu et al., 2005; Wang \& Finn, 2013; Yoo et al., 2000). Therefore, the authors suggest the following hypothesis:

- $\quad \mathrm{H} 2$ : Brand associations have a positive impact on brand equity.

\subsection{Perceived quality}

Keller (2013) defined that perceived quality is customers' recognition of the overall quality or prominence of a service or product compared to alternatives. Perceived quality is different from the objective or actual quality of the product (Zeithaml, 1988). Perceived quality is a perception by customers. It thus differs from actual or objective quality - the extent to which the product or service delivers superior service. Perceived quality will directly influence purchasing decisions and brand loyalty. Customers often choose brands with higher perceived quality (Yoo et al., 2000). Many previous studies showed that perceived quality is positively related to brand equity (Aaker, 1991; Atilgan et al., 2005; Musekiwa et al., 2013; Nguyen, Barrett, \& Miller, 2011; Pappu et al., 2005; Sanyal \& Datta, 2011; Wang \& Finn, 2013; \& Yoo et al., 2000). So, the following hypothesis is given:

- H3: Perceived quality has a positive impact on brand equity.

\subsection{Brand loyalty}

Brand loyalty is a deeply held pledge to rebuy a product/service in the future (Oliver, 1999). Keller (2013) has concluded that brand loyalty creates barriers that make it difficult for other firms to enter the market and provides predictability and security of demand for the firm. Brand loyalty makes consumers purchase a brand regularly and resist 
switching to another brand; therefore, brand equity will increase (Yoo et al., 2000). The existence of loyal customers also diminishes opportunities for competitors, frustrating them in finding ways to entice customers because of the high cost but low efficiency. During the growth stage, the overall strategy changes from acquisition to retention and building brand loyalty (Ferrell \& Hartline, 2011). Strong brands are always identified and guaranteed by loyal customers. At the same time, finding a new customer will be far costlier than maintaining old customers. In addition, loyal customers give the company a huge benefit by introducing its products to other customers. Researchers have concluded that brand loyalty has a significant positive effect on brand equity (Atilgan et al., 2005; Fatema, Azad, \& Masum, 2015; Musekiwa et al., 2013; Pappu et al., 2005; Wang \& Finn, 2013; \& Yoo et al., 2000). Therefore, the authors propose the final hypothesis:

- H4: Brand loyalty has a positive impact on brand equity.

\section{METHODOLOGY}

Structural equation modelling (SEM) was used to estimate parameters (Figure 1). There are 18 items in brand equity measures shown in the path diagram; There are four variables were available for brand awareness (AW1, AW2, AW3 and AW4), four variables for brand associations (AS1, AS2, AS3 and AS4), four variables for perceived quality (PQ1, PQ2, PQ3 and PQ4), three variables for brand loyalty (LO1, LO2 and LO3) and three variables for brand equity (BE1, BE2 and BE3). In addition, the questionnaire also used a rating scale to measure the variables of the personal information such as gender, age, income level. All items are measured by 5-point Likert scales, which were 5) strongly agree, 4) agree, 3) not sure, 2) disagree, and 1) strongly disagree.

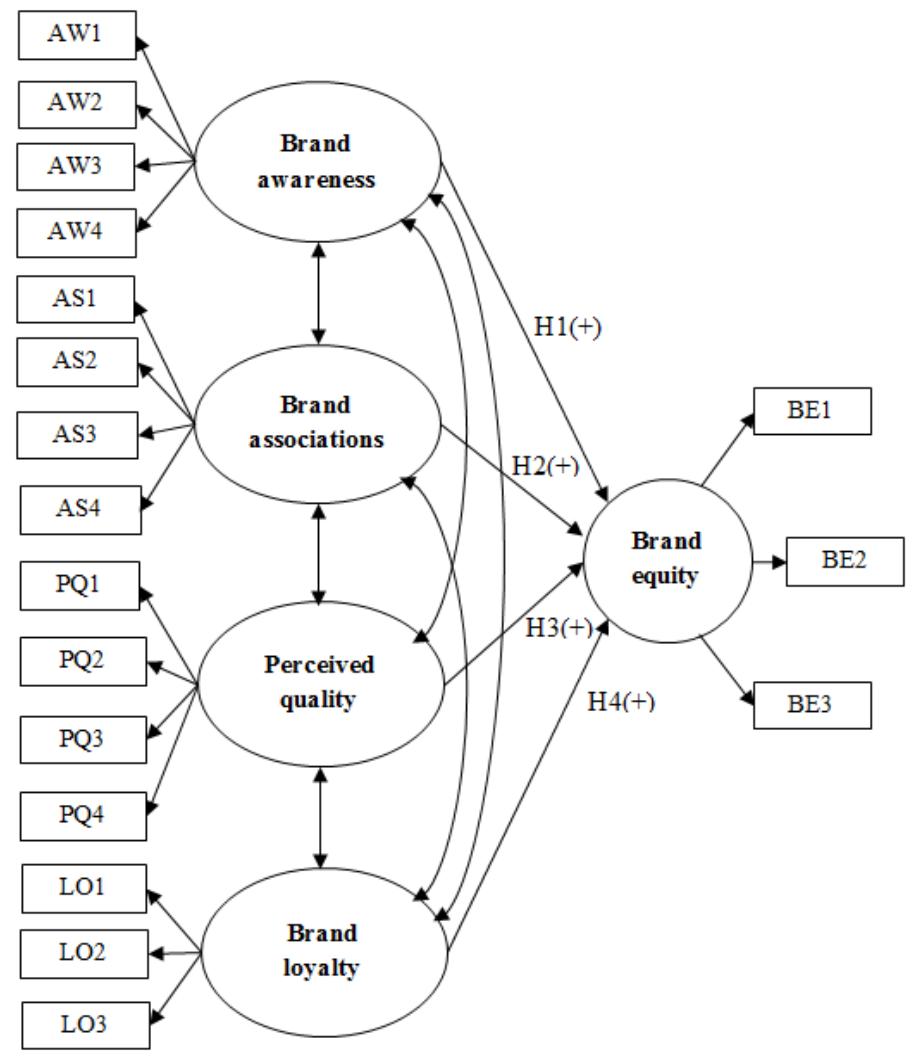

Figure 1. The Structural model and hypotheses 
Hair, Black, Babin, and Anderson (2010) confirmed that the sample size must be at least 100 in order to use the Exploratory Factor Analysis (EFA). Besides, in Confirmatory Factor Analysis (CFA) and SEM, Anderson and Gerbing (1988) suggested a sample size of at least 150 to obtain parameter estimates of practical use. Bentler and Chou (1987) proposed that the ratio of sample size to the number of free parameters may be 5:1 under the normal theory, especially when there are many indicators of latent variables. According to Tabachnick and Fidell (2013), 300 cases or more provide a good sample size for factor analysis.

In this study, the authors use a total of 328 customers selected by non-probability sampling methods (i.e. convenience sampling technique) at some large hospitals, pharmacies in Hochiminh City and Dongnai province. The demographic collection below has shown the diversity of the sample (Table 1).

Table 1. Demographic characteristics of respondents

\begin{tabular}{llll}
\hline \multirow{2}{*}{ Variable } & Description & \multicolumn{2}{c}{ Frequency } \\
\cline { 3 - 4 } & & Count & Percentage \\
\hline Gender & Male & 141 & 43.0 \\
\multirow{2}{*}{ Age (years) } & Female & 187 & 57.0 \\
& Below 25 & 139 & 42.4 \\
& $25-50$ & 149 & 45.4 \\
Monthly income range (VND) & Above 50 & 40 & 12.2 \\
& Below 5 million & 97 & 29.6 \\
& 5-20 million & 163 & 49.7 \\
& Above 20 million & 68 & 20.7 \\
\hline
\end{tabular}

\section{RESULTS AND DISCUSSIONS}

\subsection{Reliability and validity}

As can be seen from Table 2, the lowest alpha value is 0.756 . This shows a coefficient exceeding the cut of the value of 0.7 as recommended by Nunnally and Bernstein (1994). Convergent validity is verified when scores from various instruments used to measure the same construct are strongly correlated (O'Rourke \& Hatcher, 2013). Convergent validity was estimated by factor loading. The value of Kaiser-Mayer-Olkin (KMO) was 0.853 (between 0.5 and 1.0) which means that data is suitable for conducting a factor analysis. All loadings are higher than the 0.50 (Table 2). According to Hair et al. (2010), loadings \pm .50 or greater are considered practically significant. The authors also ran confirmatory factor analysis (CFA) to further test composite reliability and convergent validity. The lowest composite reliability $(\mathrm{CR})$ is 0.763 , exceeding the cut-off point 0.7 (Fornell \& Larcker, 1981). The AVE for each construct is at 0.520 or higher, exceeding the 0.5 benchmark (Fornell \& Larcker, 1981). So, composite reliability and convergent validity are demonstrated by the CFA results as well.

Discriminant validity was assessed with the variance extracted test. Discriminant validity is demonstrated if every AVE belonging to each latent variable is much more than 
any the square of correlation among any pair of latent ones (Fornell \& Larcker, 1981). So, with the result of AVE in Table 2 and the correlations between the factors in Table 3, the discriminant validity of this model is also good. The results of the CFA (Table 4) confirmed that the hypothesized model provides a good fit to the data.

Table 2. Results of factor analysis and reliability tests

\begin{tabular}{|c|c|c|}
\hline Items & Question & Factor loading \\
\hline \multicolumn{3}{|c|}{ Brand awareness $($ Cronbach's Alpha $=0.803 ; \mathrm{CR}=0.813 ; \mathrm{AVE}=0.523)$} \\
\hline AW1 & I am aware of $X$. & 0.712 \\
\hline AW2 & I can quickly recall the symbol, logo or slogan of X. & 0.769 \\
\hline AW3 & I can recognize $\mathrm{X}$ among other competing brands. & 0.776 \\
\hline AW4 & I can recognize $\mathrm{X}$ by dominant colors. & 0.627 \\
\hline \multicolumn{3}{|c|}{ Brand associations $($ Cronbach's Alpha $=0.849 ; \mathrm{CR}=0.838 ; \mathrm{AVE}=0.574)$} \\
\hline AS1 & I trust $X$. & 0.545 \\
\hline AS2 & Some characteristics of this brand come to my mind quickly. & 0.617 \\
\hline AS3 & This brand has unique associations. & 0.905 \\
\hline AS4 & $\mathrm{X}$ is a market leader brand. & 0.895 \\
\hline \multicolumn{3}{|c|}{ Perceived quality $($ Cronbach's Alpha $=0.848 ;$ CR $=0.841 ;$ AVE $=0.571)$} \\
\hline PQ1 & Buying $\mathrm{X}$ was a really good decision. & 0.859 \\
\hline PQ2 & $\mathrm{X}$ is the well-known brand. & 0.692 \\
\hline PQ3 & X's products are of high quality. & 0.773 \\
\hline PQ4 & Price for $\mathrm{X}$ is reasonable. & 0.684 \\
\hline \multicolumn{3}{|c|}{ Brand loyalty $($ Cronbach's Alpha $=0.756 ; \mathrm{CR}=0.763 ; \mathrm{AVE}=0.520$ ) } \\
\hline LO1 & $\mathrm{X}$ would be my first choice. & 0.734 \\
\hline $\mathrm{LO} 2$ & I will be willing to pay more for X's products. & 0.642 \\
\hline LO3 & I will not buy other brands if $\mathrm{X}$ is available at the store. & 0.780 \\
\hline \multicolumn{3}{|c|}{ Brand equity (Cronbach's Alpha $=0.880 ; \mathrm{CR}=0.857 ; \mathrm{AVE}=0.667$ ) } \\
\hline $\begin{array}{l}\text { BE1 } \\
\text { purcha }\end{array}$ & $\begin{array}{l}\text { If another brand is not different from } \mathrm{X} \text { in any way, it seems smarter to } \\
\text { s. }\end{array}$ & 0.831 \\
\hline BE2 & Even if another brand has the same features as X, I would prefer to buy X. & 0.760 \\
\hline BE3 & If there is another brand as good as X, I prefer to buy X. & 0.855 \\
\hline
\end{tabular}

Table 3. Correlation matrix

\begin{tabular}{llllll}
\hline & $\begin{array}{l}\text { Brand } \\
\text { awareness }\end{array}$ & $\begin{array}{l}\text { Brand } \\
\text { associations }\end{array}$ & $\begin{array}{l}\text { Perceived } \\
\text { quality }\end{array}$ & $\begin{array}{l}\text { Brand } \\
\text { loyalty }\end{array}$ & $\begin{array}{l}\text { Brand } \\
\text { equity }\end{array}$ \\
\hline Brand awareness & 1.000 & 0.291 & 0.449 & 0.314 & 0.562 \\
Brand associations & 0.291 & 1.000 & 0.519 & 0.408 & 0.557 \\
Perceived quality & 0.449 & 0.519 & 1.000 & 0.702 & 0.880 \\
Brand loyalty & 0.314 & 0.408 & 0.702 & 1.000 & 0.781 \\
Brand equity & 0.562 & 0.557 & 0.880 & 0.781 & 1.000 \\
\hline
\end{tabular}


Table 4. CFA's results

\begin{tabular}{lllllll}
\hline Chi-square & Df & Chi-square/df & GFI & TLI & CFI & RMSEA \\
\hline 303.688 & 124 & 2.449 & 0.911 & 0.932 & 0.945 & 0.067 \\
Suggested cut-off values & $\leq 3$ & $>0.7$ & & & $<0.1$ \\
\hline
\end{tabular}

Source: Segars and Grover (1993); Bentler and Chou (1987); MacCallum, Browne, and Sugawara (1996); and Segars and Grover (1993).

SEM's results showed that Chi-square $(\mathrm{CMIN})=303.688$ and degrees of freedom $(\mathrm{df})=124, \mathrm{CMIN} / \mathrm{df}=2.449<3$ (Segars \& Grover, 1993). Root mean square error of approximation $($ RMSEA $)=0.067(<0.1)$ is also indicated an acceptable level of fit for the model (MacCallum et al., 1996; Segars \& Grover, 1993). Besides that, goodness-of-fit index $(\mathrm{GFI})=0.911$, Tucker Lewis index $(\mathrm{TLI})=0.932$ and comparative fit index $(\mathrm{CFI})=$ 0.945 are higher than the cut-off value of 0.7 (Bentler \& Chou, 1987) suggested that the model fits the data well (Figure 2).

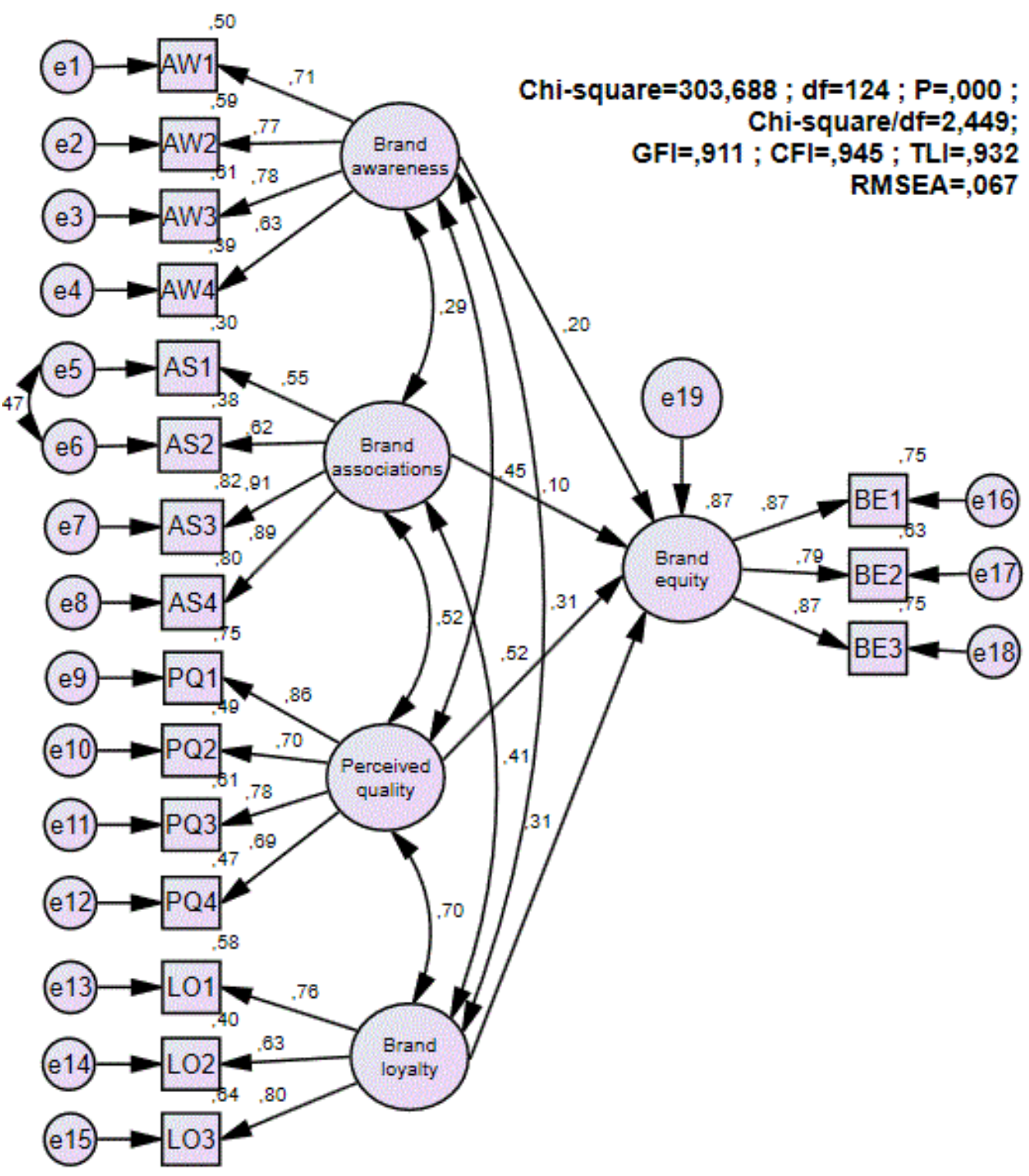

Figure 2. SEM's results 


\subsection{Hypothesis testing}

Critical ratio (C.R.) and $\mathrm{P}$ were used to test the significance of hypotheses. C.R. should be greater than 1.96 based on the significance level of 0.05 . Those values under 1.96 are not considered to be an important parameter in the model. Table 5 shows the regression coefficients and values of C.R. and P associated with each hypothesis.

Table 5. Hypothesis testing results

\begin{tabular}{llllllll}
\hline Hypotheses & Path & & & $\begin{array}{l}\text { Regression } \\
\text { coefficients }\end{array}$ & C.R & P & Result \\
\hline H1 & Brand awareness & $\rightarrow$ & Brand equity & 0.215 & 4.582 & 0.000 & Supported \\
H2 & Brand associations & $\rightarrow$ & Brand equity & 0.094 & 2.467 & 0.014 & Supported \\
H3 & Perceived quality & $\rightarrow$ & Brand equity & 0.603 & 7.059 & 0.000 & Supported \\
H4 & Brand loyalty & $\rightarrow$ & Brand equity & 0.325 & 5.068 & 0.000 & Supported \\
\hline
\end{tabular}

As reported in Table 5, brand awareness has effects on brand equity with a path coefficient of 0.215 . Brand associations have effects on brand equity with a path coefficient of 0.094 . Perceived quality has effects on brand equity with a path coefficient of 0.603 . Finally, brand loyalty has effects on brand equity with a path coefficient of 0.325 . So, all the four hypotheses are supported.

All the four hypotheses were supported in this study (Table 5). As a result, brand awareness, brand associations, perceived quality and brand loyalty have a positive impact on brand equity, especially the strong impact of perceived quality on brand equity. The reason is that pharmaceutical products are directly related to human health, and customers will choose a pharmaceutical brand when they feel the quality of the products is good. This conclusion is complement to previous studies by other authors. Pharmaceutical companies can change their strategy according to the results to increase the factors that help improve their brand equity. The regression indicates that an increase in any one of the dimensions will be followed by an increase in brand equity (see Table 5). Under conditions of limited resources, a company can focus on perceived quality and brand loyalty - the most efficient way of improving brand equity. However, it is important to note that the best results of an increase in brand equity require an increase in all factors. The results also show a correlation between the factors, especially there are two strong correlations (i.e. brand associations and perceived quality; brand loyalty and perceived quality) (Table 3). Some studies of previous authors had similar results (Dlacic \& Kezman, 2014; Nguyen et al., 2011; Pappu et al., 2005; \& Yoo et al., 2000).

Although several articles have been published to analyse factors affecting brand equity, this study aims at the applications of those analyses in pharmaceutical companies in general and Vietnamese pharmaceutical companies in particular, because knowing the factors affecting on consumer-based brand equity of pharmaceutical companies and the relationship between them can help companies improve their brand equity most conveniently and effectively. 


\section{CONCLUSIONS AND RECOMMENDATIONS}

The research results show that there are four factors affecting consumer-based brand equity of Vietnamese pharmaceutical companies: Brand awareness; Brand associations; Perceived quality; and Brand loyalty. The impact level is as follows: Perceived quality $>$ Brand loyalty $>$ Brand awareness $>$ Brand associations. In this study, the authors also found a high correlation amongst these two determinants of brand equity (i.e. perceived quality and brand loyalty).

The study demonstrates Vietnamese pharmaceutical companies' composition of brand equity, and complements previous studies of other authors. However, due to limited time and resources, the research was conducted on only a small scale. Future studies will be continued on a larger scale and with more generalization. Policies to improve brand equity are suggested through the following factors:

- Perceived quality factor: To increase perceived quality, the company must invest in product innovations, change the product's shape and packing methods, researching and developing products to create products of higher quality than other pharmaceutical brands'. Besides, they need to provide highquality customer services and conduct utilize valuation methods to offer the best price and maintain a competitive edge over other brands.

- Brand loyalty factor: Brand loyalty can be improved by setting a reasonable commission rate, paying attention to promotions to stimulate the market and offering gifts on holidays and anniversaries for distributors, wholesalers, etc.

- Brand awareness factor: There are many ways to improve brand awareness. The authors suggest the following ways: creating different brands, each being connected to the parent brand, creating products of different and unique colors and designs, increasing the use of leaflets on pharmaceutical products in pharmacies and hospitals, offering free gifts-with-purchase with the company's logo, such as pens, raincoats, etc and utilizing emails and messages to send notifications to target customers.

- Brand associations factor: The company should increase the frequency of appearing in the media by advertising or interviewing and inviting celebrities to serve as brand ambassadors to represent the company or products.

\section{REFERENCES}

Aaker, D. A. (1991). Managing brand equity: Capitalizing on the value of a brand name. New York, USA: The Free Press.

Aaker, D. A. (1996). Building strong brands. New York, USA: The Free Press.

Anderson, J. C., \& Gerbing, D. W. (1988). Structural equation modeling in practice: A review and recommended two-step approach. Psychological Bulletin, 103(3), 411423.

Atilgan, E., Aksoy, Ş., \& Akinci, S. (2005). Determinants of the brand equity: A verification approach in the beverage industry in Turkey. Marketing Intelligence \& 
Planning, 23(3), 237-248.

Bentler, P. M., \& Chou, C. P. (1987). Practical issues in structural modeling. Sociological Methods \& Research, 16(1), 78-117.

Business Monitor International. (2018). Vietnamp pharmaceuticals and healthcare report. London, UK: Business Monitor International Research.

Business Sweden. (2015). Opportunities in Vietnam's healthcare sector. Hanoi, Vietnam: Business Sweden in Vietnam.

Chen, A. C. H. (2001). Using free association to examine the relationship between the characteristics of brand associations and brand equity. Journal of Product \& Brand Management, 10(7), 439-451.

Christodoulides, G., Cadogan, J. W., \& Veloutsou, C. (2015). Consumer-based brand equity measurement: Lessons learned from an international study. International Marketing Review, 32(3/4), 307-328.

Dlacic, J., \& Kezman, E. (2014). Exploring relationship between brand equity and customer loyalty on pharmaceutical market. Economic and Business Review for Central and South-Eastern Europe, 16(2), 121-131.

Farquhar, P. H. (1989). Managing brand equity. Marketing Research, 1(3), 24-33.

Fatema, M., Azad, M. A. K., \& Masum, A. K. M. (2015). Impact of brand image and brand loyalty in measuring brand equity of Islami Bank Bangladesh Ltd. Asian Business Review, 2(1), 42-46.

Ferrell, O. C., \& Hartline, M. (2011). Marketing strategy ( $5^{\text {th }}$ ed.). Mason, USA: SouthWestern Cengage Learning.

Fornell, C., \& Larcker, D. F. (1981). Evaluating structural equation models with unobservable variables and measurement error. Journal of Marketing Research, 18(1), 39-50.

Hair, J. F., Black, W. C., Babin, B. J., \& Anderson, R. E. (2010). Multivariate data analysis ( $7^{\text {th }}$ ed.). New Jersey, USA: Pearson Prentice Hall.

Hoang, T. A. T. (2016). The impact of advertising and promotion on brand equity: The case of the FMCG supermarket industry in Hue. VNU Journal of Science: Economics and Business, 32(4), 49-58.

Keller, K. L. (1993). Conceptualizing, measuring, and managing customer-based brand equity. Journal of Marketing, 57(1), 1-22.

Keller, K. L. (2013). Strategic brand management: Building, measuring, and managing brand equity ( $4^{\text {th }}$ ed.). New Jersey, USA: Pearson Prentice Hall.

Lassar, W., Mittal, B., \& Sharma, A. (1995). Measuring customer-based brand equity. Journal of Consumer Marketing, 12(4), 11-19.

MacCallum, R. C., Browne, M. W., \& Sugawara, H. M. (1996). Power analysis and determination of sample size for covariance structure modeling. Psychological Methods, 1(2), 130-149. 
Musekiwa, A., Chiguvi, D., \& Hogo, H. (2013). Customer-based retail brand equity (RBE) dimensions effect on retail brand equity for OK supermarket in Bindura. International Journal of Business and Management, 8(19), 45-52.

Nunnally, J. C., \& Bernstein, I. H. (1994). Psychometric theory ( $3^{\text {rd }}$ ed.). New York, USA: McGraw-Hill.

Ngo, T. N. H., Nguyen, V. B., \& Dinh, T. M. (2014). Components of brand equity: The case of Binhthuan dragon fruit. Journal of Economic Development, (222), 142-160.

Nguyen, T. D., Barrett, N. J., \& Miller, K. E. (2011). Brand loyalty in emerging markets. Marketing Intelligence \& Planning, 29(3), 222-232.

O'Rourke, N., \& Hatcher, L. (2013). A step-by-step approach to using SAS for factor analysis and structural equation modeling ( ${ }^{\text {nd }}$ ed.). North Carolina, USA: SAS Institute.

Oliver, R. L. (1999). Whence consumer loyalty? The Journal of Marketing, 63(special), $33-44$.

Panchal, S. K., Khan, B. M., \& Ramesh, S. (2012). Importance of 'brand loyalty, brand awareness and perceived quality parameters' in building brand equity in the Indian pharmaceutical industry. Journal of Medical Marketing, 12(2), 81-92.

Pappu, R., Quester, P. G., \& Cooksey, R. W. (2005). Consumer-based brand equity: Improving the measurement - empirical evidence. Journal of Product \& Brand Management, 14(3), 143-154.

Río, A. B. D., Vázquez, R., \& Iglesias, V. (2001). The effects of brand associations on consumer response. Journal of Consumer Marketing, 18(5), 410-425.

Sanyal, S. N., \& Datta, S. K. (2011). The effect of perceived quality on brand equity: An empirical study on generic drugs. Asia Pacific Journal of Marketing and Logistics, 23(5), 604-625.

Segars, A. H., \& Grover, V. (1993). Re-examining perceived ease of use and usefulness: A confirmatory factor analysis. MIS Quarterly, 17(4), 517-525.

Tabachnick, B. G., \& Fidell, L. S. (2013). Using multivariate statistics (6 $6^{\text {th }}$ ed.). New Jersey, USA: Pearson Prentice Hall.

Vázquez, R., Del Rio, A. B., \& Iglesias, V. (2002). Consumer-based brand equity: Development and validation of a measurement instrument. Journal of Marketing Management, 18(1-2), 27-48.

Wang, L., \& Finn, A. (2013). Heterogeneous sources of customer-based brand equity within a product category. Marketing Intelligence \& Planning, 31(6), 674-696.

Yoo, B., Donthu, N., \& Lee, S. (2000). An examination of selected marketing mix elements and brand equity. Journal of the Academy of Marketing Science, 28(2), 195-211.

Zeithaml, V. A. (1988). Consumer perceptions of price, quality, and value: A means-end model and synthesis of evidence. The Journal of Marketing, 52(3), 2-22. 